\section{Mycosporine-Like Compounds in Chlorolichens: Isolation from Dermatocarpon luridum and Dermatocarpon miniatum, and their Photoprotective Properties}

\section{Thi Thu Tram Nguyen, Marylène Chollet-Krugler, Françoise Lohézic-Le Dévéhat, Isabelle Rouaud, Joël Boustie}

Institut des Sciences Chimiques de Rennes, UMR CNRS 6226, Equipe PNSCM "Produits Naturels - Synthèses - Chimie Médicinale», UFR Sciences Pharmaceutiques et Biologiques, Université de Rennes 1, Université Européenne de Bretagne, Rennes, France

\section{Abstract \\ $\nabla$}

Two mycosporines were isolated for the first time in two chlorolichen species, Dermatocarpon luridum and Dermatocarpon miniatum. Mycosporine glutaminol (1) and mycosporine glutamicol (2) were isolated along with the ethyl ester of mycosporine glutamicol (3), which was formed during the purification process. Aqueous extracts and pure mycosporines were then investigated for their antioxidant activities and photoprotective properties along with their photostability and photocytotoxicity. Semi-purified mycosporine fractions were much more antioxidant than lichen aqueous crude extracts. Compound $3\left(\mathrm{IC}_{50}=4.00 \mu \mathrm{g} / \mathrm{mL}\right)$ was found to be as active as quercetin ( $\mathrm{IC}_{50}=6.75 \mu \mathrm{g} / \mathrm{mL}$ ), while the two genuine mycosporines $\mathbf{1}$ and $\mathbf{2}$ exhibited moderate activity. The three mycosporines were found to be stable until $5 \mathrm{~J} /$ $\mathrm{m}^{2}$ UVA and UVB radiations whereas Trolox, used as a positive control, was degraded up to $10 \%$ and $19 \%$, respectively. Moreover, these mycosporines and semi-purified extracts did not induce any phototoxicity on HaCaT cells exposed to UVA radiations.

Key words

Dermatocarpon luridum · Dermatocarpon miniatum • Verrucariaceae $\cdot$ lichen $\cdot$ mycosporine-like amino acids (MAAs) · photoprotection

$\begin{array}{ll}\text { Abbreviations } \\ \text { DL1: } & \text { crude aqueous extract of } D \text {. luridum } \\ \text { DL2: } & \text { semi-purified aqueous extract of } D \text {. luridum } \\ \text { DM1: } & \text { crude aqueous extract } D \text {. miniatum } \\ \text { DM2: } & \text { semi-purified aqueous extract of } D \text {. miniatum } \\ \text { MAAs: } & \text { mycosporine-like amino acids } \\ \text { PDA: } & \text { photodiode array } \\ \text { PIF: } & \text { photo-irritancy factors }\end{array}$

Supporting information available online at http://www.thieme-connect.de/products

Mycosporine-like compounds comprising mycosporines and MAAs have received much attention for their putative role in UV photoprotection as antioxidants and osmoprotectants [1-4]. Mycosporine-like compounds are small water-soluble molecules composed of cyclohexenone (oxo-mycosporine) or cyclohexenimine (imino-mycosporine) ring structures conjugated to an ami- no acid or an amino alcohol subunit. They are characterized by a unique strong peak in the wavelength range of $310-365 \mathrm{~nm}$ $\left(\varepsilon=28000-50000 \mathrm{M}^{-1} \cdot \mathrm{cm}^{-1}\right)$. About 40 mycosporines and derivatives have been described so far, and some of them are substituted with functional groups or are covalently bound to saccharidic units [5-8]. Such UV-absorbing compounds are distributed in taxonomically diverse organisms of terrestrial, marine, or freshwater origin [9]. More recently, the distribution of mycosporinelike compounds has been reported in cyanolichens (symbiotic organisms resulting from an association between a fungus and a cyanobacterium) [10,11]. Although chlorolichens correspond to $90 \%$ of lichen species, mycosporine-like compounds have not yet been described in chlorolichens in which cyanobacteria are replaced by green algae. Their secondary metabolite profile is generally characterized by a variety of specific phenolic compounds, and most of them have UV absorbing properties [2,12]. A previous phytochemical screening revealed that chlorolichens belonging to the Dermatocarpon genus (Verrucariaceae) did not contain the usual lichen substances such as depsides, depsidones, dibenzofurans, xanthones, and anthraquinones, which are considered photoprotectants [13-16]. In the present study, we have investigated two Dermatocarpon species for their photoprotective compounds: Dermatocarpon luridum and Dermatocarpon miniatum containing Diplosphaera chodatii (Trebouxiophyceae) photobionts [17]. A phytochemical study led to the isolation and identification of three mycosporines. The aqueous extracts and purified mycosporines were tested for their antioxidant activities, photostability, and photocytotoxicity.

To investigate $D$. luridum and $D$. miniatum for mycosporine-like compounds, a protocol previously described [10] was used to extract lichen material with water $\left(+4^{\circ} \mathrm{C}\right)$ followed by semi-purification on cation exchange resin chromatography (see Supporting Information). The HPLC-DAD-MS ${ }^{2}$ analysis of DL2 and DM2 revealed the presence of three mycosporines, $\mathbf{1}, \mathbf{2}$, and 3 , with an absorption maximum at $310 \mathrm{~nm}$ ( Table 1). These compounds were then isolated from an aqueous extract of $D$. luridum ( $5 \mathrm{mg}$, $6.5 \mathrm{mg}$, and $6 \mathrm{mg}$, respectively) and their structures were determined by ESI ${ }^{+}$-HRMS, NMR, and IR spectra (Figs. 1.1S-3.8S, Supporting Information). Spectroscopic analysis and MS data comparison of compounds $\mathbf{1}$ and $\mathbf{2}$ with the literature [6] led to the identification of mycosporine glutaminol (1) $\left(\mathrm{m} / \mathrm{z}[\mathrm{M}+\mathrm{H}]^{+} 303\right)$ and mycosporine glutamicol (2) $\left(\mathrm{m} / \mathrm{z}[\mathrm{M}+\mathrm{H}]^{+} 304\right)$. As lichens are symbiotic organisms, involvement of their respective partners in the biogenesis of mycosporines should be elucidated. Until now, cyanobacteria were supposed to produce mycosporinelike compounds in cyanolichens [10]. Thus far, mycosporines 1 and $\mathbf{2}$ and their glycolysed derivates have been described in various terrestrial ascomycetous fungi [18-21]. In addition, compound 1 has also been detected in the terrestrial cyanobacteria Leptolyngbya sp. [6] and compound 2 in the cyanolichen Degelia plumbea [10]. As no green algae are described to date to synthesize these mycosporines, the fungal partner may also be involved in the biosynthesis of mycosporines $\mathbf{1}$ and $\mathbf{2}$, especially since mycosporine described in lichens have the characteristic carbonyl moiety of fungal mycosporines. Compound $3\left(\mathrm{~m} / \mathrm{z}[\mathrm{M}+\mathrm{H}]^{+} 332\right)$ did not correspond to any previously described mycosporine and ESI $^{+}$-HRMS revealed a $\mathrm{C}_{15} \mathrm{H}_{25} \mathrm{NO}_{7}$ molecular formula differing from mycosporine glutamicol by $m / z 28$ (Fig. 3.2S, Supporting Information). Its IR spectrum showed a large band in the 3200 $3650 \mathrm{~cm}^{-1}$ range indicating the presence of hydroxyl and amino groups, two strong bands at 1665 and $1712 \mathrm{~cm}^{-1}$ corresponding to an $\alpha, \beta$-unsaturated ketone group and a carbonyl ester group, 
Table 1 Physicochemical properties and mass fragmentation pattern of mycosporines 1, 2, and $\mathbf{3}$.

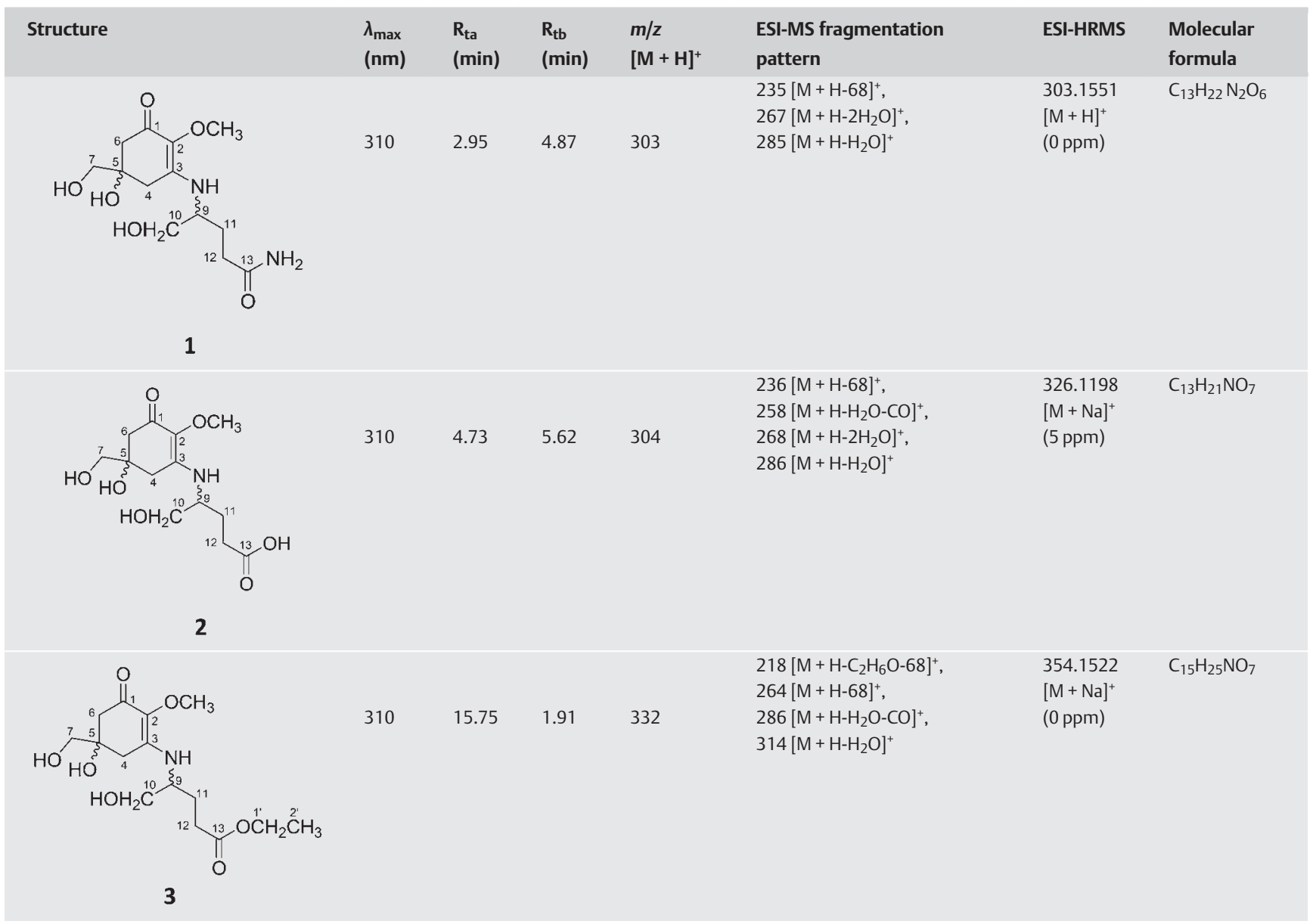

$\mathrm{R}_{\mathrm{ta}}$ : retention time on HPLC-DAD-MS² using a Zorbax Eclipse XDB-C18 $(3.5 \mu \mathrm{m}, 150 \times 2.1 \mathrm{~mm})$ column; $\mathrm{R}_{\mathrm{tb}}$ : retention time on HPLC-DAD using a Kinetex HILIC $100 \AA$ ( $2.6 \mu \mathrm{m}$, $100 \times 4.60 \mathrm{~mm}$ ) column

respectively (Fig. 3.1S, Supporting Information). ${ }^{1} \mathrm{H},{ }^{13} \mathrm{C}-\mathrm{NMR}$, COSY, and HMBC correlations were in full agreement with the structure of 3 (Figs. 3.35-3.85, Supporting Information). Compound $\mathbf{3}$ was supposed to be formed by the esterification between mycosporine glutamicol and ethanol, containing some acidic traces, during $\mathrm{NaCl}$ removal in the semi-purification step. Indeed, many MAAs can be converted to their methyl esters by treatment with $\mathrm{HCl}$-methanol [1]. Comparison of the crude and the semi-purified aqueous extracts using HPLC-DAD-MS ${ }^{2}$ analysis confirmed that compound $\mathbf{3}\left(\mathrm{R}_{\mathrm{t}}=15.75 \mathrm{~min}\right)$ was a by-product as only found in the semi-purified extract ( $\bullet$ Fig. 1).

Regarding the strong absorption of the genuine mycosporines 1 and 2 at $310 \mathrm{~nm}$ in the UVA-UVB overlap region (molar extinction coefficients $12542,17248 \mathrm{M}^{-1} \cdot \mathrm{cm}^{-1}$, respectively) ( Fig. 2), we assume that mycosporines $\mathbf{1}$ and $\mathbf{2}$ may be partly involved in the photoprotection of these lichens [2]. Therefore, we investigated some biological activities related to UV filter requirements including the ethyl derivative 3 , which exhibited a higher molar extinction coefficient $21295 \mathrm{M}^{-1} . \mathrm{cm}^{-1}$. Until now, most mycosporine-like compounds tested for their antioxidant activities are either pure imino-mycosporines or a mixture of several imino-mycosporines [7,22-26]. Thus, oxo-mycosporines are less reported, and only mycosporine glycine and mycosporine glutaminol glucoside have been tested so far [23,27-29]. So, the antioxidant properties using DPPH and NBT assays of the pure oxo-mycospor- ines 1, 2, and $\mathbf{3}$ along with aqueous lichen extracts which contain 1and $\mathbf{2}$ were evaluated ( Table 2). DL2 and DM2 were slightly more active than their respective crude extracts DL1 and DM1, while the three mycosporines displayed weak electron transfer activity, as shown in the DPPH assay. At $80 \mu \mathrm{g} / \mathrm{mL}$, the semi-purified extracts DL2 and DM2 with a higher mycosporine concentration (data not shown) scavenged, respectively, 2-fold and 4-fold more superoxide anion than the crude extracts DL1 and DM1. Likewise, DM2 $\left(\mathrm{IC}_{50}=5.20 \pm 2.20 \mu \mathrm{g} / \mathrm{mL}\right)$ was more active than DL2 $\left(\mathrm{IC}_{50}=11.00 \pm 5.00 \mu \mathrm{g} / \mathrm{mL}\right)$, which appeared also to be correlated with the mycosporine concentration. However, the activity of the individual mycosporines $\mathbf{1}$ and $\mathbf{2}$ were found to be moderate (no IC ${ }_{50}$ could be determined). The esterification of the mycosporine glutamicol carboxyl group resulted in a significant superoxide anion scavenging activity increase with a better activity $\left(\mathrm{IC}_{50}=4.00 \mu \mathrm{g} / \mathrm{mL}\right)$ of compound 3 compared to the standard quercetin $\left(\mathrm{IC}_{50}=6.75 \mu \mathrm{g} / \mathrm{mL}\right)$.

Looking for UV protectants, photostability under UVA and UVB, and low toxicity on cells before and after UVA irradiation are prerequisites. Aqueous solutions of the DM2 and the three mycosporines were irradiated under six UV doses covering the UVA and UVB range. By-products of the positive control Trolox appeared at $0.5 \mathrm{~J} / \mathrm{m}^{2}$ exposures, and a $10 \%$ and $19 \%$ degradation rate was observed at $5 \mathrm{~J} / \mathrm{m}^{2}$ exposures to UVA and UVB, respectively. Concerning DM2 and the three mycosporines, no degradation oc- 


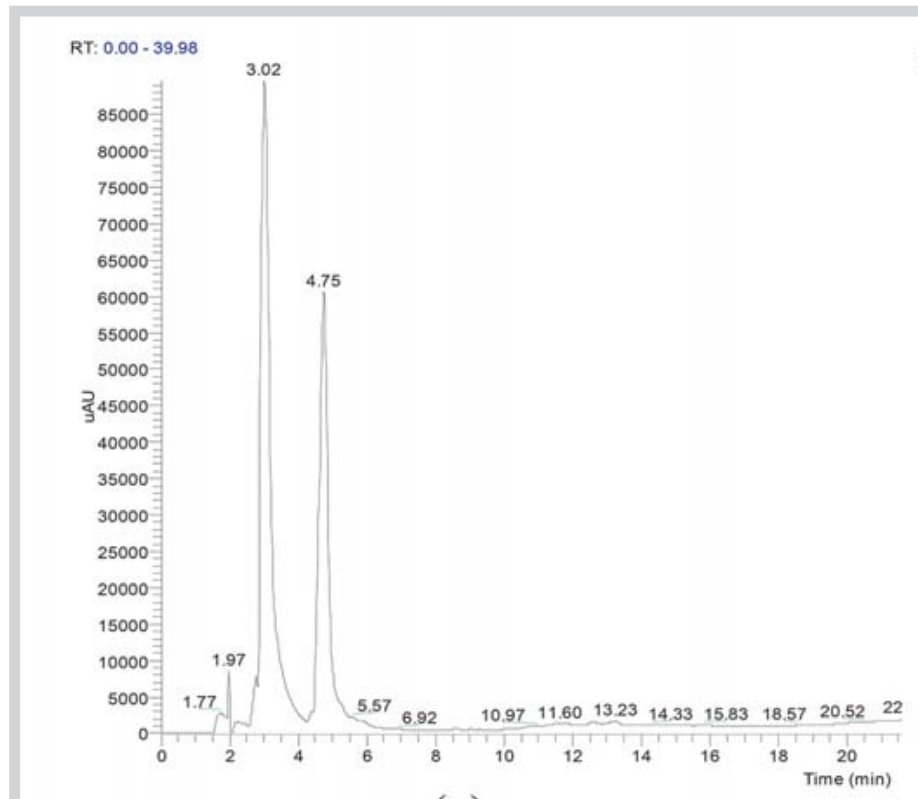

(a)

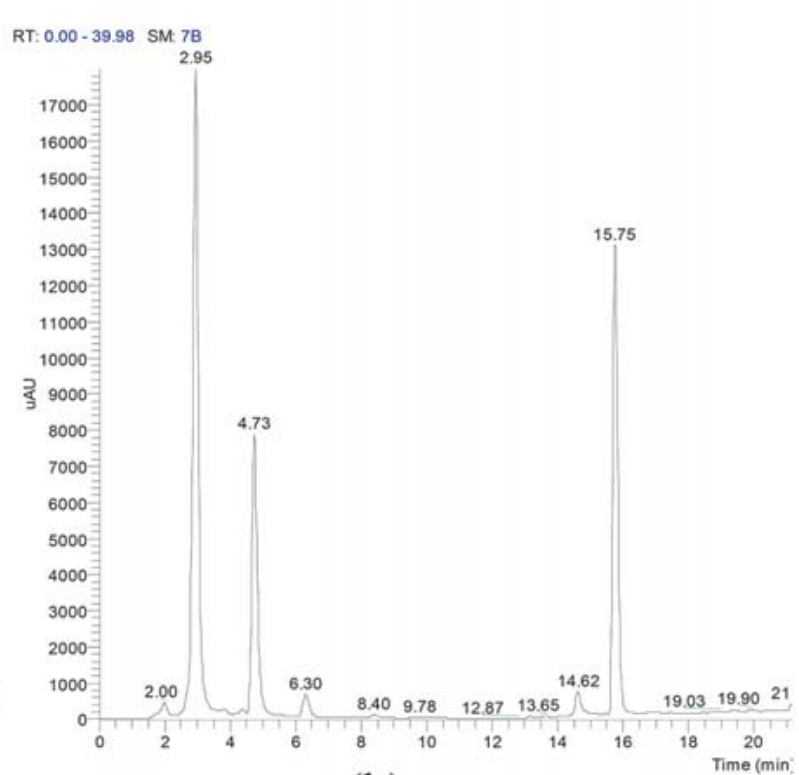

(b)

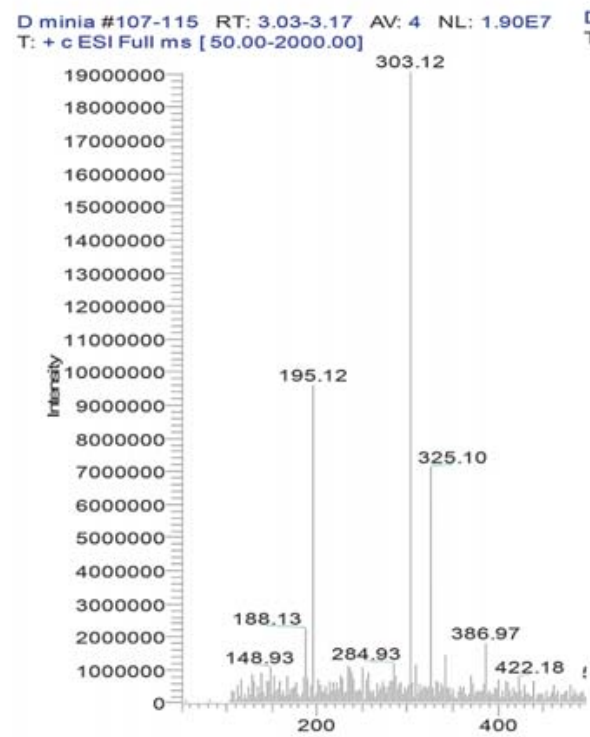

(c)

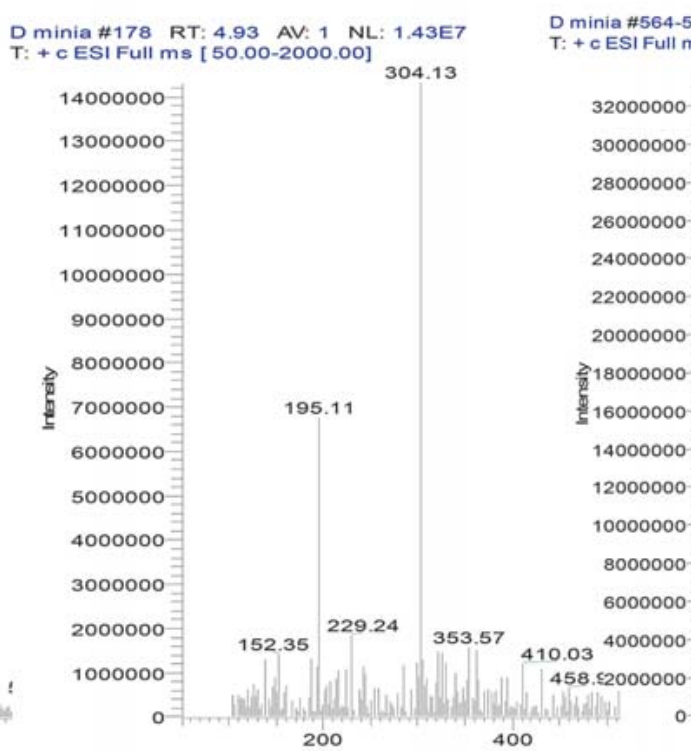

(d)

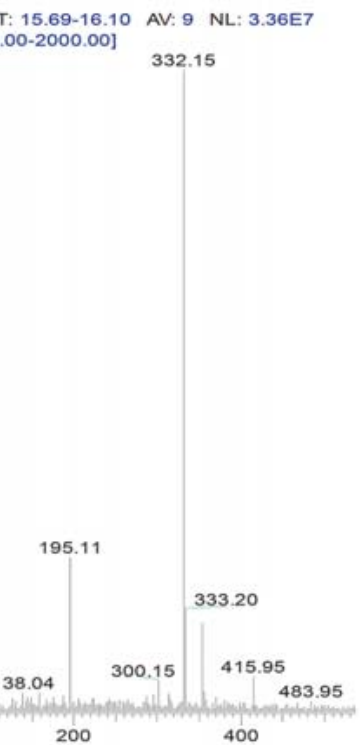

(e)

Fig. 1 PDA chromatograms of DM1 (a) and DM2 (b); MS spectra of mycosporines $\mathbf{1}$ (c), $\mathbf{2}$ (d), and $\mathbf{3}$ (e) extracted at Rt= 3.02, 4.93, and 15.75 min, respectively.

curred even at $5 \mathrm{~J} / \mathrm{m}^{2}$ (Fig. 5S, Supporting Information). These results confirmed the absence of photoproducts observed by Moliné et al. when mycosporine-glutaminol-glucoside was subjected to UVB irradiation [29].

According to clinical and experimental studies, noncytotoxic doses of many chemicals could, however, induce phototoxic responses when exposed to non-phototoxic doses of UV radiation $[30,31]$. In this way, the PIF values of the mycosporines and extracts were determined and compared to the positive chlorpromazine control highlighting a phototoxic effect with a PIF $>5$ ( Table 3). Except a slight PIF=1.1 calculated for compound 2, no cytotoxicity with or without UVA irradiation could be ob- served for the other tested compounds and extracts. These PIF values $<<5$ suggest that these lichen extracts and mycosporines are non-phototoxic.

In regards to their good photostability, non-photocytotoxicity, and their antioxidant activities, mycosporines and the semi-purified aqueous extracts appear to be considered as eligible candidates for photoprotection and further developed with regard to Helioguard ${ }^{\mathrm{R}}$. 


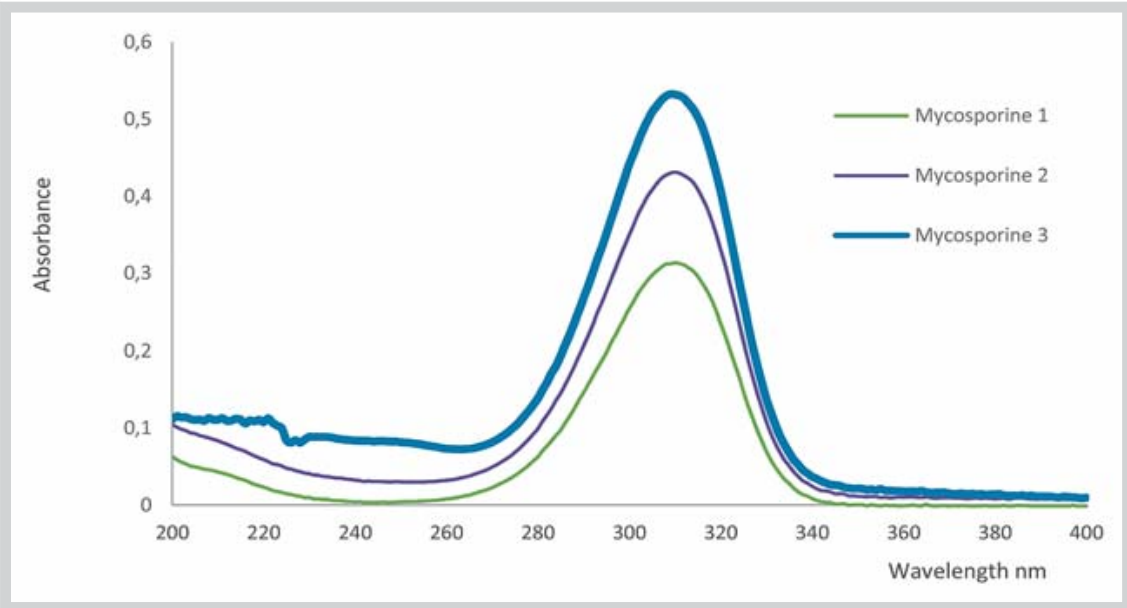

Fig. 2 UV absorption spectra of mycosporines 1 , $\mathbf{2}$, and $\mathbf{3}$ in water at $\mathrm{C}=2.5 \times 10^{-5} \mathrm{M}$.

\begin{tabular}{lcc} 
Extract/mycosporine & $\begin{array}{c}\text { \% Inhibition } \\
\text { DPPH method }\end{array}$ & NBT method \\
\hline DL1 & $5.2 \pm 2.0$ & $44.6 \pm 15.7$ \\
\hline DL2 & $18.4 \pm 3.9$ & $80.2 \pm 9.8$ \\
DM1 & $13.6 \pm 5.7$ & $21.5 \pm 12.3$ \\
\hline DM2 & $24.8 \pm 6.2$ & $86.4 \pm 2.5$ \\
\hline$(\mathbf{1})$ & $1.9 \pm 2.3$ & $42.1 \pm 2.2$ \\
\hline (2) & $0.5 \pm 0.8$ & $44.6 \pm 5.8$ \\
(3) & $30.4 \pm 3.3$ & $85.4 \pm 1.4$ \\
Quercetin & $100.0 \pm 0.1$ & $100.0 \pm 0.1$ \\
\hline
\end{tabular}

Table 2 Antioxidant activity of the aqueous extracts and mycosporines $\mathbf{1}, \mathbf{2}$, and $\mathbf{3}$ through DPPH free radical scavenging activity and superoxide anion scavenging ability (NBT method). Activity is expressed as \% inhibition at the maximum dose (400 and $80 \mu \mathrm{g} /$ $\mathrm{mL}$, respectively).

DL1: crude aqueous extract, DL2: semi-purified aqueous extract of $D$. luridum; DM1: crude aqueous extract, DM2: semi-purified aqueous extract of $D$. miniatum. (1): Mycosporine glutaminol; (2): mycosporine glutamicol; (3): ethyl ester of mycosporine glutamicol

\begin{tabular}{|llll|}
\hline Extract/mycosporine & $\begin{array}{l}\text { Photocytotoxic activities on HaCaT cells } \\
\text { IC } 50 \pm \text { SD }(\boldsymbol{\mu g} / \mathbf{m L})\end{array}$ & Photo-irritancy factor (PIF) \\
& Without irradiation & With irradiation & \\
\hline DL1 & $>40$ & $>40$ & ${ }^{*} 1^{b}$ \\
\hline DL2 & $>40$ & $>40$ & ${ }^{*} 1^{b}$ \\
\hline DM1 & $>40$ & $>40$ & ${ }^{*} 1^{b}$ \\
\hline DM2 & $>40$ & $>40$ & ${ }^{*} 1^{b}$ \\
\hline$(1)$ & $>40$ & $>40$ & ${ }^{*} 1^{b}$ \\
\hline$(2)$ & $30.0 \pm 6.0$ & $27.0 \pm 4.0$ & $1.1^{c}$ \\
\hline$(3)$ & $>40$ & $>40$ & ${ }^{*} 1^{b}$ \\
\hline Chlorpromazine & & $3.5 \pm 0.0$ & $6.3^{c}$ \\
\hline
\end{tabular}

Table 3 Cytotoxic and photocytotoxic activities of the aqueous extracts and mycosporines.

DL1: crude aqueous extract, DL2: semi-purified aqueous extract of $D$. luridum; DM1: crude aqueous extract, DM2: semi-purified aqueous extract of D. miniatum. (1): Mycosporine glutaminol; (2): mycosporine glutamicol; (3): ethyl ester of mycosporine glutamicol. aphotocytotoxic positive control; ${ }^{b}$ formal PIF $=C_{\max }(-U V) / C_{\max }(+U V)$; ; formal PIF $=I C_{50}(-U V) / I C_{50}(+U V)$

\section{Materials and Methods \\ $\nabla$ \\ Lichen material}

D. luridum (With.) J.R. Laundon was collected in Huelgoat, Brittany, France (April 2012). D. miniatum (L.) W. Mann was collected in Moëlan-sur-Mer, Brittany, France (September 2013). The lichens were identified by Jean-Yves Monnat (biologist, University of Bretagne Sud, France). Voucher specimens were deposited in the herbarium of Pharmacognosy and Mycology, University of Rennes 1, France with reference numbers JB/12/001 and JB/13/ 004, respectively.
Extraction and isolation of mycosporines

Lichen material was macerated with pure water at $+4^{\circ} \mathrm{C}$ to give a crude aqueous extract. The extract was purified by the cation exchange resin Dowex to remove sugars and polyols. Next, a purification protocol including bare silica-HILIC flash chromatography, open reverse-phase column chromatography, and semi-preparative HPLC-DAD was applied to the semi-purified extract to isolate compounds $\mathbf{1}, \mathbf{2}$, and $\mathbf{3}$. The detailed extraction and isolation of the three compounds as well as ESI-HRMS, IR, and NMR data of the compounds are available as Supporting Information 


\section{Supporting information}

The general experimental procedures, optimized extraction and purification method followed by HPLC-DAD-MS ${ }^{2}$ analysis, extraction and isolation of mycosporines as well as the copies of their HRMS, IR, ${ }^{1} \mathrm{H},{ }^{13} \mathrm{C}, 2 \mathrm{D}$ NMR spectra, antioxidant assays, photostability under UVA and UVB, and cytotoxic and photocytotoxic activities are available as Supporting Information.

\section{Acknowledgements}

\section{$\nabla$}

The authors would like to thank Jean-Yves Monnat for collecting the lichens and his valuable support with identification. We would like to thank the Vietnamese government for a PhD grant to Thi Thu Tram Nguyen.

\section{Conflict of Interest}

There is no conflict of interest among all authors.

\section{References}

1 Carreto JI, Carignan MO. Mycosporine-like amino acids: relevant secondary metabolites. Chemical and ecological aspects. Mar Drugs 2011; 9: 387-446

2 Nguyen KH, Chollet-Krugler M, Gouault N, Tomasi S. UV-protectant metabolites from lichens and their symbiotic partners. Nat Prod Rep 2013; 30: 1490-1508

3 Oren A, Gunde-Cimerman N. Mycosporines and mycosporine-like amino acids: UV protectants or multipurpose secondary metabolites? FEMS Microbiol Lett 2007; 269: 1-10

4 Sinha R, Sinha RP. Biomedical applications of mycosporine-like amino acids. In: Kim SK, editor. Marine microbiology: bioactive compounds and biotechnological applications. Weinheim: Wiley-VCH; 2013: 509-526

5 Volkmann M, Whitehead K, Rütters H, Rullkötter J, Gorbushina AA. Mycosporine-glutamicol-glucoside: a natural UV-absorbing secondary metabolite of rock-inhabiting microcolonial fungi. Rapid Commun Mass Spectrom 2003; 17: 897-902

6 Volkmann M, Gorbushina AA. A broadly applicable method for extraction and characterization of mycosporines and mycosporine-like amino acids of terrestrial, marine and freshwater origin. FEMS Microbiol Lett 2006; 255: 286-295

7 Matsui K, Nazifi E, Kunita S, Wada N, Matsugo S, Sakamoto T. Novel glycosylated mycosporine-like amino acids with radical scavenging activity from the cyanobacterium Nostoc commune. J Photochem Photobiol B 2011; 105: 81-89

8 Nazifi E, Wada N,Yamaba M, Asano T, Nishiuchi T, Matsugo S, Sakamoto T. Glycosylated porphyra-334 and palythine-threonine from the terrestrial cyanobacterium Nostoc commune. Mar Drugs 2013; 11: 3124-3154

9 Balskus EP, Walsh CT. The genetic and molecular basis for sunscreen biosynthesis in cyanobacteria. Science 2011; 329: 1653-1656

10 Roullier C, Chollet-Krugler M, Pferschy-Wenzig EM, Maillard A, Rechberger GN, Legouin-Gargadennec B, Bauer R, Boustie J. Characterization and identification of mycosporines-like compounds in cyanolichens. Isolation of mycosporine hydroxyglutamicol from Nephroma laevigatum Ach. Phytochemistry 2011; 72: 1348-1357

11 La Barre S, Roullier C, Boustie J. Mycosporine-like amino acids (MAAs) in biological photosystems. In: La Barre S, Kornprobst J-M, editors. Outstanding marine molecules. Weinheim: Wiley-VCH; 2014: 333349

12 Boustie J, Tomasi S, Grube M. Bioactive lichen metabolites: alpine habitats as an untapped source. Phytochem Rev 2010; 10: 287-307

13 Lindberg B, Misiorny A, Wachtmeister CA. Studies on the chemistry of lichens. Acta Chem Scand 1953; 7: 591-595

14 Ramakrishnan S, Sankara SS. Amino-acids of Dermatocarpon moulinsii. Curr Sci 1966; 35: 284-285

15 Czeczuga B, Olech M. Investigations on carotenoids in lichens. XXV. Studies of carotenoids in lichens from Spitsbergen. Phyton 1990; 30: 235-245

16 Duman DC, Aras S, Atakol O. Determination of usnic acid content in some lichen species found in Anatolia. J Appl Biol Sci 2008; 2: 41-44
17 Fontaine KM, Beck A, Stocker-Wörgötter E, Piercey-Normore MD. Photobiont relationships and phylogenetic history of Dermatocarpon luridum var. luridum and related Dermatocarpon species. Plants 2012; 1: 39-60

18 Fayret J, Bernillon J, Bouillant ML, Favre-Bonvin J, Arpin N. Open and ring forms of mycosporine-2 from the Ascomycete Gnomonia leptostyla. Phytochemistry 1981; 20: 2709-2710

19 Pittet JL, Bouillant ML, Bernillon J, Arpin N. Sur la presence de mycosporines-glutamine reduites, nouvelles molecules, chez plusieurs Deutéromycètes. Tetrahedron Lett 1983; 24: 65-68

20 Pittet JL, Létoublon R, Frot-Coutaz J, Arpin N. Soluble uridine diphosphoD-glucose: mycosporin glucosyltransferase from spores of Ascochyta fabae Speg. Planta 1983; 159: 159-164

21 Sinha RP, Singh SP, Häder DP. Database on mycosporines and mycosporine-like amino acids (MAAs) in fungi, cyanobacteria, macroalgae, phytoplankton and animals. J Photochem Photobiol B 2007; 89: 29-35

22 Rastogi RP, Incharoensakdi A. UV radiation-induced accumulation of photoprotective compounds in the green alga Tetraspora sp. CU2551. Plant Physiol Biochem 2013; 70: 7-13

23 De la Coba F, Aguilera J, Figueroa FL, Gálvez MV, Herrera E. Antioxidant activity of mycosporine-like amino acids isolated from three red macroalgae and one marine lichen. J Appl Phycol 2009; 21: 161-169

24 Nakayama R, Tamura Y, Kikuzaki H, Nakatani N. Antioxidant effect of the constituents of Susabinori (Porphyra yezoensis). JAOCS 1999; 76: 649-653

25 Yoshiki M, Tsuge K, Tsuruta Y, Yoshimura T, Koganemaru K, Sumi T, Matsui T, Matsumoto K. Production of new antioxidant compound from mycosporine-like amino acid, porphyra-334 by heat treatment. Food Chem 2009; 113: 1127-1132

26 Rastogi RP, Incharoensakdi A. UV radiation-induced biosynthesis, stability and antioxidant activity of mycosporine-like amino acids (MAAs) in a unicellular cyanobacterium Gloeocapsa sp. CU2556. J Photochem Photobiol B 2014; 130: 287-292

27 Dunlap WC, Yamamoto Y. Small-molecule antioxidants in marine organisms: antioxidant activity of mycosporine-glycine. Comp Biochem Physiol 1995; 112 B: 105-114

28 Yakovleva I, Bhagooli R, Takemura A, Hidaka M. Differential susceptibility to oxidative stress of two scleractinian corals: antioxidant functioning of mycosporine-glycine. Comp Biochem Physiol Part B 2004; 139: 721-730

29 Moliné M, Arbeloa EM, Flores MR, Libkind D, Farías ME, Bertolotti SG Churio MS, van Broock MR. UVB photoprotective role of mycosporines in yeast: photostability and antioxidant activity of mycosporine-glutaminol-glucoside. Radiat Res 2011; 175: 44-50

30 Jones $P$. In vitro phototoxicity assays. In: Chilcott RP, Price S, editors. Principles and practice of skin toxicology. Chichester: Wiley \& Sons; 2008: $169-181$

31 Lohézic-Le Dévéhat F, Legouin B, Couteau C, Boustie J, Coiffard L. Lichenic extracts and metabolites as UV filters. J Photochem Photobiol B 2013; 120: $17-28$

received July 26,2014

revised December 26, 2014

accepted January 15, 2015

\section{Bibliography}

Dol http://dx.doi.org/10.1055/s-0034-1396321

Planta Med Lett 2015; 2: e1-e5

(c) Georg Thieme Verlag KG Stuttgart · New York .

ISSN 2199-157X

\section{Correspondence}

\section{Dr. Marylène Chollet-Krugler}

UMR CNRS 6226, Institut des Sciences Chimiques de Rennes Equipe PNSCM «Produits Naturels - Synthèses - Chimie Médicinale»

UFR Sciences Pharmaceutiques et Biologiques

Université de Rennes 1, Université Européenne de Bretagne

2 Av. du Pr. Léon Bernard

35043 Rennes

France

Phone: +33223234896

Fax: +33223234704

marylene.chollet@univ-rennes1.fr
License terms (9) (1) $\Theta \circledast$ 